DOI: $10.28934 /$ jwee18.12.pp31-39

PRELIMINARY REPORTS

\title{
An Institutional Approach to Female Entrepreneurship in Nigeria
}

\author{
Ann Terngu Makar Vandefan ${ }^{1}$ \\ University of Business Academy, FIMEK, Novi Sad, Serbia
}

\begin{abstract}
A B S T R A C T
With the increase in population and unemployment rates globally, especially in developing countries like Nigeria, government of most nationals are unable to provide adequate jobs for their teeming population. This study is to ascertain the Institutional Approach to Female entrepreneurship in Nigeria. There are about 37,067,416 micro businesses and 36,994,578 Small and 4,670 Medium Scale businesses respectively in Nigeria (SMEDAN 2010, SMEDAN 2013 \& SMEDAN 2015). Female entrepreneurs accounted for ownership of $43.32 \%$ of Micro enterprises and $22.75 \%$ of Small and Medium enterprises respectively (NEPZA 2013). Yet there is no clear Institutional Approach to Female Entrepreneurship in Nigeria. The focus of this article is to explain the reasons for the lack of institutional approach and proffer ways to developing same. This is imperative in order to develop institutional frameworks for providing effective support for female entrepreneurs.
\end{abstract}

KEY WORDS: female entrepreneurship, small and medium enterprises Nigeria

\footnotetext{
${ }^{1}$ PhD Candidate, University of Business Academy, FIMEK, Cvecarska 2, Novi Sad, Serbia, e-mail: magtvan@gmail.com
} 


\section{Introduction}

The way women have contributed immensely to national and world economic growth and development cannot be overemphasized. This has made women empowerment and development as one of the issues that have gained tremendous attention by individuals, governments and NonGovernmental Organizations (NGO's) across the globe. The momentous interest attached to women empowerment and equal opportunities to the world over is due to the consideration fact that women constitute $49.56 \%$ large number of the world's population with about $(3,710,260,959)$ females out of the world's population of 7,486,520,598 as at 31 December 2016 out of 7,486,520,598 world's population constituting about $49.56 \%$ of the world Population, with The female population in Nigeria that stand approximately at $94,349,729$ out of the 191,137,487 of the Nigerian Population (UNESCO, 2003). Thus women make up to $49.36 \%$ of the estimated Nigerian Population (UN-Women, 2014). The interest in women empowerment is also due to the consideration of their greater contribution to the development of the society. According to Spevacek (2010) the concept of promoting women's economic and political empowerment has gained some much attention for decades. Verheul et al. (2006), observed that this is attributable to the fact that female entrepreneurs are now considered important forces in economic development of their nations (Kirk and Belovics, 2006). According to Okezie, et al. (2013) thee are of the opinion that the need for entrepreneurship development today is required by the fact that entrepreneurship development plays as a key factor in economic growth and development and also it is the permanent solution for extreme hunger and poverty which is caused by unemployment. Ikeije and Onuba (2015) are of the belief that entrepreneurship is an area that has attracted the interest of various researchers, academics, and government as well as private individuals. Researchers in this field of study have adopted multidisciplinary approach in the study of entrepreneurship. Accor4ding to scholars like Clausen (2006) and Ikeije and Onuba (2015), there is an extensive and increased interest about the study of entrepreneurship skills in Nigeria. This renewed interest in the study and application of entrepreneur ship skills is based on the realization that it will enhance skills acquisition, open up job opportunities and reduce unemployment, reduce the poverty levels among women and enhance economic growth and development.

Ikeije and Onuba (2015) agreed that there is increased research about entrepreneurship that has encouraged researchers in diverse fields to devote 
more time in understanding the driving forces behind entrepreneurship. The increased interest in this new field is prominent in areas of studies such as economic, political considerations, environmental realities and socio cultural factors. Both Adejumo (2000) and Anyadike, et al. (2012) agreed that entrepreneurship has a lot of contribution to the development of advance economies and to this understanding the under developed world should not under estimate its contribution to its economic planning.

Entrepreneurship skills will no doubt contribute to the increased economic activities of any growing economy in the areas of job creation and is also capable of improving the quality of living of families and contributing positively in the overall domestic growth of a nation. Entrepreneurship Studies by (Thomas and Mueller, 2000; Reynolds, 1987) has demonstrated how its (entrepreneurship) relationship is capable of positively stimulating growth economically and increased employment of labor and resources and has can also empower the less privileged in societies.

According to (Anyadike, et al. 2012,). Josiane (1998) in Ayogu and Agu (2015), entrepreneurship is considered as an engine that mobilizes economic growth and a vessel that stimulate economic development and is acknowledged as a very important avenue of creating jobs, enhance revenue generation, reduce poverty and increase wealth generation.

According to the United Nations research on small and medium scales published in 2006, entrepreneurship is an essential tool that supports the development and growth of both the small and medium size enterprises in developing economies and is central in job opportunities for skills and semi skills labor force (United Nations, 2006 in Ayogu and Agu, 2015).

Studies by Sowmya et al. (2010) in Mazlina and Punitha (2016, p. 224) attest to this that entrepreneurship is essential aspect for growth and development of most countries after the global financial crisis and economic downturn. Entrepreneurship is also considered one of the major economic drivers for both advance economies and under developed ones (Ramadani, Hisrich and Gerguri, 2015; Hisrich, Bowser and Smarsh, 2006).

It is the realization of the importance of entrepreneur ship to economic development that has resulted to rapid studies in the field by many business schools around the world; this is because this field has been realized by many countries as a pillar to growth and development and as an avenue to be your own employer and generate profit has attracted people to entrepreneur ship skills equitation. (Rose, Kumar and Lim, 2006). Agbeze 
(2012), quoted in Anya dike, Emeh, and Ukah (2012) believes that there are various business potentials in Nigeria due to its abundant human and natural resources it possess; they both agreed that utilizing these resources depends on the ability to identify useful and viable economic fields of endeavor. They both agreed that Nigerians have made remarkable progress in the areas of science, technology, business, agriculture, academics and entertainment sectors. They further stated that, it is in this regards that Nigeria enterprise has been greatly developed in agriculture and other related agro allied industries like food restaurants, food vendor etc. Nigerians hve also made their marks in diverse fields such as science, technology, academics, business and entertainment.

Entrepreneurship activities and innovative ingenuity in Nigeria have developed enterprises in the areas of solid minerals explorations, quarrying, and germ stone cutting/polishing and crushing engineering. Also there is a remarkable achievement in power generation, transportation and Haulage business (cargo and passengers). Also there are a lot of Nigerians in information technology where they repair mobile handsets and sales of accessories, printing and selling of recharge cards. They are also visible in hospitality and tourism enterprises such as hotels, resort centers and events management. Nigerians are found in banking and other financial services and in building and construction departments where there are plan and design services and material sourcing too (Agbeze, 2012 in Anyadike, Emeh, and Ukah).

For many developing countries, entrepreneurship has been a powerful engine of economic growth and wealth creation, and is crucial for improving the quality, number and variety of employment opportunities for the poor (Oteh, 2009). Ikeije and Onuban (2015, p. 6) reasoned the same way with Oteh (2009) when he reiterated that there is a correlation between economic growth and the level of entrepreneurial activity. A study by Global Entrepreneurship Monitor (2008) as cited in Ikeije and Onuba (2015) revealed that economic growth of a country is directly correlated to its level of entrepreneurial activity. Oteh, 2009 in Ikeije and Onuba (2015) points out the benefits of entrepreneurship on the economic development of a country like Nigeria when he wrote:

Entrepreneurship has many multiplier effects on the economy, spurs innovation, and fosters investment in people, which is a better source of competitive advantage than other natural resources, which can be depleted. Entrepreneurs create new enterprises, new commercial activities, and new 
economic sectors. They generate jobs for others; they produce goods and services for society; they introduce new technologies and improve or lower cost outputs; and they earn foreign exchange through export expansion or the substitution of imports.

Entrepreneurship has assisted in providing gainful employments to the teaming youths in communities and cities and it is an avenue for many young men and women to get jobs in informal sectors of the economy where they work in small scale or medium scale industries or establish their own small firms that render services to bigger firms and industries. (Ikeije and Onuba, 2015). Entrepreneurship has been one area where domestic resources are mobilized while they serve as contributory factor to disposal of industrial waste. They also serve as a source of semi processed raw materials for the utilization by bigger factories. Entrepreneur skills have been a vital source for acquiring semi skilled and skilled work experience by many Nigerians.

It is a base for the development of appropriate technology and provides a veritable ground for skilled, unskilled and semi-skilled workers (Ikeije and Onuba, 2015). It provides productive self-employment to a number of educated and less educated young men and women coming. (Ikeije and Onuba, 2015). According to Radovic-Markovic et. al., (2017), "e-learning programs specially designed for entrepreneurs can be used as a tool for empowering female and young people's competencies in ountries with inadequate system of formal education." Since this can be an encouragement to the individual and will also establishes entrepreneurial culture wider. Saskia (2016) agreed that there are a lot of benefits in female entrepreneurship skills that is considered as a gold mine by nations as an avenue for economic growth and a new untapped area for wome $4 \mathrm{n}$ empowerment that should not be ignored by any developing country.

The focus of this article is to examine the role of women entrepreneur in Nigeria and the various policies provided by the Nigerian government that are capable of providing the needed support for women engage in small and medium scale enterprise

\section{Research Question}

This study addresses several questions below:

i. What are the available opportunities in Nigerian economy for women entrepreneurs? 
ii. How effective has women entrepreneurs being in economic development of the country?

iii. What are the available institutional frame works in Nigeria for female entrepreneurs?

\section{Methodology: Population and Sample}

This research work will look at the six geo political zones of Nigeria and then select one state from each of the zones as the sample study area these will be the North East, North West, North Central, South East, South West, and South-South, and the Federal Capital Territory. The following states will be the selected states for the study are in each of the zones. Benue from North Central, Taraba form North East, Kaduna from North West, Enugu from South East, Cross River from South-South, Lagos from South West and FCT Abuja. The women entrepreneurs in these states will be the sample size and 400 women will be randomly selected as the sample population.

\section{Method of Data Collection and Analysis}

The research will be conducted using both the secondary and primary sources of data collection. The interviews and questionnaires will be employed as primary sources of data while the secondary source will be published works, journals, qualitative and quantitative techniques will be employed in data analysis and interpretations.

\section{Results and Discussion}

The data in this study will be analyzed using quantitative and qualitative approaches. Data collected through questionnaire will be analyzed through the use of descriptive statistics while data collected through the use of the interviews will be analyzed qualitatively using thematic, analytical, interpretative and explanatory approaches.

\section{Conclusion}

There are various phases that need to be considered for women entrepreneurs to be empowered they differ from a particular culture to 
another culture. In some cultures, women work in different areas for them to be able to provide the basic needs for the family and in certain times, they are permanently involved in just working at home doing all the household jobs (Brush et al, 2009; Garba, 2011). For women to be successful entrepreneurs it has to do with the environment they find themselves and this is normally subjected to situations involving political and economic culture and national policies. (Garba, 2011 and Emmanuel, 2013). These factors play an important role by helping to reduce the challenges that women entrepreneurial faces in many ways.

The Government should try as much as possible in providing the needed resources and facilities for women through their various associations and different forums that are available to them in their communities. This will help enhancing entrepreneurship and development for a sustainable economic change through the needed capital. From time to time women should be educated with the needed skills and educational knowledge for enable them participate effectively in an enabling environment (GEM, 2012).

\section{References}

[1] Achtenhagen and Welter 2011. Surfing on the Ironing Board. Entrepreneurship and Regional Development, 23: 763-786.

[2] Adebimpe, A. 2011 Assessing Nigerian female entrepreneur's access to finance for business start-up and growth. African Journal of Business Management, 5(13), 5348-5355, Available online at: http://www.academicjournals.org/AJBM

[3] Adeoye, A. 2015. The Effect of Entrepreneurship on Economy Growth and Development in Nigeria. International Journal of Development and Economic Sustainability, 3(2): 49-65.

[4] Agarwal, J. 1999. Ethical Work Climate Dimensions in a Not-for-Profit Organization: An Empirical Study. Journal of Business Ethics, 20(1): 1-14.

[5] Agu, O. E. and Ayogu, U. D. 2015. Assessing the Prospects and Problems of Entrepreneurship Development in Nigeria. International of Current Research and Academic Review, 3(10): 208-221.

[6] Akinola, A. O. 2013. Entrepreneurship in Nigeria-Funding and Financing Strategies. European Journal of Accounting Auditing and Finance Research, 1(4): 115-128.

[7] Alex, M. 2008. Entrepreneurial services marketing initiatives facilitating small business growth. Journal of Small Business and Entrepreneurship, 21(4): 493-502. 
[8] Anyadike, N.; Emeh, I. E. J. and Ukah, F. O. 2012. Entrepreneurship development and employment generation in Nigeria: Problems and prospects.Universal Journal of Education and General Studies, 1(4) pp. 088102, Available online at http://www.universalresearchjournals.org/ujegs.

[9] Brush, C. D and Bruin A. D. and Welter, F. 2009. A Gender Aware framework for Women's Entrepreneurship. International Journal of Gender and Entrepreneurship, 1(1): 8-28.

[10] Cantzler, I. and Leijon, S. (2007). Team Orientated Women entrepreneurs: A way to Modern Management. Journal of Small Business and Enterprise Development, 14(4): 732-746.

[11] Emmanuel, C.L. 2013. Entrepreneurship, A Conceptual Approach, Second Edition, Pumark Nigeria Limited: 353-358.

[12] Garba, S. A. 2011. Stumbling Block for Women Entrepreneurship in Nigeria: How Risk Attitude and Lack of Capital Mitigates their Need for Business Expansion. European Journal of Economics, Finance and Administrative Sciences, 36: 38-49.

[13] Hisrich, R. D. and Ozturk, S. A. 1999. Women entrepreneurs in a developing economy. The Journal of Management Development, (18): 11424.

[14] Ikeduru, N. G. 2002. Women Entrepreneurship and Development: The Gendering of Microfinance in Nigeria. A paper presented at the 8th International Interdisciplinary Congress on Women, 21 - 26 July, 2002. Makerere University, Kampala, Uganda.

[15] Ikeije, U. U. and Onuba, C. O. 2015. Contributions and Challenges of Entrepreneurship in Nigeria: A Sociological Analysis. European Journal of Business and Innovation Research, 3(3): 1-9.

[16] ILO. 2012 Women's Entrepreneurship Development. Encouraging women entrepreneurs for jobs and development. Published online, http://www.ilo.org/wed

[17] Kirks J, Bolvics R. 2006. Counseling Would-be Entrepreneurs. J. Employment Counselling, 43(2): 50-62.

[18] Mordi, C., Simpson, R., Singh, S. \& Okafor, C. 2010. The Role of Cultural Values in Understanding the Challenges faced by Female Entrepreneurs in Nigeria, Gender in Management: An International Journal, 25(1): 5-21.

[19] NEPZA. 2013. "National Enterprise Development Programme (NEDEP)." $\begin{array}{llll}\text { Retrieved } & 7^{\text {th }} & \text { April, } & \text { 2018, }\end{array}$ http://www.nepza.gov.ng/downloads/nedep.pdf.

[20] Okezie, A. I.; Alex, O. and Asoluta, N. 2013. Challenges and Prospects of Entrepreneurship in Nigeria. Academic Journal of Interdisciplinary Studies, 2(5): 25-35. 
Vandefan, M.T A., Female Entrepreneurship in Nigeria, JWEE (2018, No. 1-2, 31-39) 39

[21] Radovic-Markovic, M. et al. 2017. E-Learning as a Tool for Empowering Entrepreneurship. Journal of Women's Entrepreneurship and Education, 34/2017: 1-27.

[22] Radovic-Markovic, M. 2013. "Female Entrepreneurship: Theoretical Background. Journal of Women's Entrepreneurship and Education, 2013/12: 1-9.

[23] Saskia, V. 2016. Gender-Aware Women's Entrepreneurship Development for Inclusive Development in Sub-Saharan Africa. Gender Advisory and Knowledge Services, Netherland Ministry of Foreign Affairs.

[24] Spevacek, M. A. 2010. Constraints to Female Entrepreneurship in SubSaharan Africa. Research Series, United States Agency for International Development, June 17.

[25] SMEDAN. 2010. "2010 National MSME Collaborative Survey." from http://www.smedan.gov.ng/images/collaborative\%20survey\%20report.smed an-nbs.pdf.

[26] SMEDAN. 2013. "SMEDAN and NBS Collaborative Survey: Selected findings." $\quad$ Retrieved $10 \quad$ April, 2018 fromhttp://nigerianstat.gov.ng/pdfuploads/SMEDAN\%202013_Selected\%20 Tables.pdf.

[27] SMEDAN 2015. "National Policy on MSMEs." Retrieved 10th July, 2016, from

http://www.smedan.gov.ng/images/NBS2015/NATIONAL\%20POLICY\%20 ON\%20MSMEsFin al\%20Copy.pdf. Vollmer, S. (2015). "7 ways to ease SMEs' access to capital markets." Retrieved $12^{\text {th }}$ April 2018, from https://www.linkedin.com/pulse/7-ways-ease-smes-access-capital-marketsrodgerstephens-cpa-cgma.

[28] Todaro, M.L. \& Smith, S.C. 2009. Economic Development, 10th Edition, Addison-Wesley, Pearson Education.

[29] UNESCO (United Nations Educational, Scientific and Cultural Organization). 2003. EFA and Global Monitoring Report 2003/4: Gender and Education for All: The Leap to Equality. Paris: UNESCO

[30] UN-Women. 2014. World Survey on the Role of Women in Development: Gender equality and Sustainable Development. Accessed at www.unwomen.org on 23.4.18.

Article history: $\quad$ Received: 4 April, 2018

Accepted: 8 June, 2018 